\title{
ANALISIS PENGGUNAAN MODUL TERHADAP KEMAMPUAN PEMAHAMAN MATERI PAJAK
}

\author{
Meyta Pritandhari ${ }^{1)}$, Wakijo $^{2)}$ \\ Pendidikan Ekonomi Fakultas Keguruan dan Ilmu Pendidikan Universitas Muhammadiyah Metro \\ meyta.pritandhari@gmail.com
}

\begin{abstract}
This study aims to analyze the use of modules on the ability to understand tax material. This research is a qualitative research with a descriptive analytical approach and is case study. The results of this study are the use of modules has a positive impact of $85 \%$ on the ability to understand tax material. With the module, student learning is no longer centered on Google alone without any other supporting references. Most students who do not have a tax material reference are helped by the taxation module. Students can easily learn taxation material systematically in accordance with the Semester Learning Plan (RPS). Understanding of tax material can be seen from the students' skills in completing evaluation questions in the tax module.
\end{abstract}

Keywords: Module, Tax, Concept Understanding

\begin{abstract}
Abstrak
Penelitian ini bertujuan untuk menganalisis penggunaan modul terhadap kemampuan pemahaman materi pajak.Penelitian ini merupakan penelitian kualitatif dengan pendekatan deskriptif analitis dan bersifat case study. Hasil penelitian ini adalah penggunaan modul mempunyai dampak positif sebesar $85 \%$ terhadap kemampuan pemahaman materi pajak. Dengan adanya modul, pembelajaran mahasiswa tidak lagi terpusat pada gooogle saja tanpa adanya referensi lain yang mendukung. Sebagian besar mahasiswa yang tidak mempunyai referensi materi perpajakan terbantu dengan adanya modul perpajakan. Mahasiswa dapat dengan mudah mempelajari materi perpajakan secara sistematis sesuai dengan Rencana Pembelajaran Semester (RPS). Pemahaman materi pajak dapat ditinjau dari ketrampilan mahasiswa dalam menyelesaikan soal evaluasi dalam modul perpajakan.
\end{abstract}

Kata Kunci: Modul, Pajak, Pemahaman Konsep 


\section{PENDAHULUAN}

Semakin canggih teknologi saat ini mempunyai dampak yang positif dan dampak negatif. Dampak positifnya adalah mahasiswa dapat dengan mudah mengakses berbagai informasi ter-update yang ada. Sedangkan dampak negatifnya adalah mahasiswa hanya mengandalkan informasi yang diakses tanpa didasari dengan teori yang jelas. Proses pembelajaran yang dilakukan oleh mahasiswa saat ini hanya mengandalkan referensi dari Google saja. Mahasiswa bahkan sedikit sekali mempunyai buku referensi dalam perkuliahan.

Salah satu alternatif yang dapat membantu mahasiswa dalam belajar adalah dengan menggunakan modul. Modul diharapkan dapat membantu mahasiswa dalam kegiatan pembelajaran. Modul sebagai referensi yang dibuat telah sesuai dengan Rencana Pembelajaran Semester (RPS) yang akan membantu mahasiswa dalam kegiatan pembelajaran. Dalam modul juga terdapat soal-soal evaluasi setiap materinya. Diharapkan dengan adanya modul dapat membantu mahasiswa dalam memahami materi pajak yang dipelajari.

Hasil penelitian dari Lasmiyati dan Harta (2014) menyimpulkan bahwa pembelajaran siswa menggunakan modul meningkat pemahaman konsep belajarnya. Minat belajar siswa meningkat dibandingkan dengan siswa yang belajar tidak menggunakan modul. Hal ini membuktikan bahwa modul sangat bermanfaat bagi siswa dalam pembelajaran sehingga modul harus dibuat untuk menunjang proses pembelajaran.

Menurut Majid (2013 : 176) Modul adalah sebuah buku yang ditulis dengan tujuan agar peserta didik dapat belajar secara mandiri tanpa atau dengan bimbingan guru. Modul dapat membuat peserta didik belajar dengan caranya masing-masing. Dengan demikian modul dapat mempermudah peserta didik belajar dengan cepat karena dalam modul terdapat rangkuman materi, dan soal evaluasi setiap babnya.

Sedangkan pendapat Prastowo (2011:107) modul adalah sebuah bahan ajar yang disusun secara sistematis dengan bahasa yang mudah dipahami oleh peserta didik sesuai tingkat pengetahuan dan usia mereka, agar mereka dapat belajar sendiri (mandiri) dengan bantuan atau bimbingan yang minimal dari pendidik. Modul sebaiknya disusun dengan bahasa yang mudah dipahami oleh pembaca sehingga isi modul dapat dengan mudah dipahami. Modul juga sebaiknya disusun berdasarkan tema materi yang akan dipelajari. Modul dengan desain yang menarik akan memberi pengaruh positif terhadap pembaca.

Menurut Jihad dan Haris (2008: 16) pemahaman (comperhension) adalah jenjang setingkat di atas pengetahuan ini meliputi penerimaan dalam komunikasi secara akurat, menempatkan hasil komunikasi dalam bentuk penyajian yang berbeda, mengorganisasikannya secara setingkat tanpa merubah pengertian dan dapat mengekplorasikan.

Jadi pemahaman adalah hasil dari penerimaan komunikasi yang dilakukan sehingga mempunyai output penilaian yang berbeda antara satu dengan yang lain sehingga dapat dikatakan bahwa pemahaman antar individu dapat berbeda. Pemahaman juga dapat dipengaruhi oleh bagaimana informasi itu didapat oleh seseorang sehingga terbentuk pola pikir berdasarkan penerimaan informasi yang sebelumnya.

Menurut Bloom (Daryanto, 2008: 106) mengemukakan bahwa Pemahaman (comprehension) kemampuan ini umumnya mendapat penekanan dalam proses belajar mengajar. Siswa dituntut untuk memahami atau mengerti apa yang diajarkan, mengetahui apa yang sedang dikomunikasikan dan dapat memanfaatkan isinya tanpa keharusan menghubungkannya dengan hal-hal lain. 
Selanjutnya kemampuan pemahaman menurut Daryanto (2008:106) kemampuan pemahaman dapat dijabarkan dibagi menjadi tiga, yaitu sebagai berikut:

a) Menerjemahkan(translation).

Pengertian menerjemahkan di sini bukan saja pengalihan (translation) arti dari bahasa yang satu ke dalam bahasa yang lain. Dapat juga dari konsepsi abstrak menjadi suatu model, yaitu model simbolik untuk mempermudah orang mempelajarinya.

b) Menginterpretasi (interpretation).

Kemampuan ini lebih luas daripada menerjemahkan, ini adalah kemampuan untuk mengenal dan memahami. Ide utama suatu komunikasi

c) Mengekstrapolasi(extrapolation).

Agak lain dari menerjemahkan dan menafsirkan, tetapi lebih tinggi sifatnya. Ia menuntut kemampuan intelektual yang lebih tinggi.

Kemampuan pemahaman bukan hanya sekedar tahu tentang sesuatu, namun lebih dari hal itu. Pemahaman yaitu kemampuan untuk lebih mendalami sesuatu, dan dapat menafsirkan kembali dengan cara yang berbeda. Pemahaman tentang sesuatu berbeda antara satu dengan yang lainnya sehingga dapat menimbulkan perbedaan pemahaman.

\section{METODE PENELITIAN}

Penelitian ini adalah deskriptif kualitatif dengan metode analitis. Menurut Tohirin (2013:2) penelitian kualitatif merupakan "penelitian yang berupaya membangun pandangan orang yang diteliti secara rinci serta dibentuk dengan kata-kata, gambaran holistik (menyeluruh dan mendalam) dan rumit.”. Ditinjau dari aspek yang diteliti, penelitian ini merupakan penelitian yang bersifat studi kasus (case study).

\section{Sumber data}

Sumber data merupakan ketepatan akurasi informasi yang diperoleh dari sumber yang valid. Dalam penelitian ini terdapat dua sumber data yaitu sebagai berikut:

a. Data primer yaitu sumber data yang didapat dari sumber utama yang dijadikan objek penelitian. Dalam hal ini yang menjadi sumber utama adalah mahasiswa pendidikan ekonomi.

b. Data sekunder yaitu sumber data yang didapat dari dokumentasi, arsip dan yang berkaitan dengan masalah penelitian. Peneliti menggunakan dokumentasi yang dapat melengkapi data primer.

\section{Teknik Sampling}

Teknik sampling yang digunakan dalam penelitian ini adalah Nonprobability sampling atau Sampel Tidak Acak. Jenis sampel ini tidak dipilih secara acak. Tidak semua unsur atau elemen populasi mempunyai kesempatan sama untuk bisa dipilih menjadi sampel. Purposive sampling adalah teknik pengambilan sampel sumber data dengan pertimbangan tertentu. Pertimbangan ini berdasarkan pertimbangan bahwa orang tersebut yang dianggap paling tahu tentang apa masalah yang dibahas. (Sugiyono, 2013:300).

\section{Validitas Data}

Menurut (Bogdan dalam Sugiyono, 2013:244) Analisis data adalah proses mencari dan menyusun secara sistematis data yang diperoleh dari hasil wawancara, catatan lapangan, dan bahan-bahan lain, sehingga dapat mudah dipahami, dan temuannya dapat diinformasikan kepada orang lain. Pemeriksaan validitas data menggunakan teknik triangulasi data. Menurut Afifuddin (2009: 143) triangulasi yaitu teknik pemeriksaan keabsahan data yang memanfaatkan sesuatu yang lain di luar data itu untuk keperluan pengecekan atau sebagai pembanding terhadap data itu. 
Menurut Patton dalam Afifuddin (2009: 143) terdapat empat macam triangulasi sebagai teknik pemeriksaan untuk mencapai keabsahan:

a) Triangulasi data menggunakan berbagai sumber data, seperti dokumen, arsip, hasil wawancara, hasil observasi atau juga dengan mewawancarai lebih dari satu subjek yag dianggap memiliki sudut pandang yang berbeda.

b) Triangulasi pengamat adanya pengamat di luar peneliti yang turut memeriksa hasil pengumpulan data. Dalam penelitian ini, misalnya pembimbing bertindak sebagai pengamat (export judgement) yang memberikan masukan terhadap hasil pengumpulan data.

c) Triangulasi teori Penggunaan berbagai teori yang berlainan untuk memastikan bahwa data yang dikumpulkan sudah memenuhi syarat.

d) Triangulasi metode Penggunaan berbagai metode untuk meneliti suatu hal, seperti metode wawancara dan metode observasi.

\section{Teknik Analisis Data}

Teknik analisis data yang digunakan dalam penelitian ini menggunakan pola penelitian induktif yang diolah dengan teknik saling terjalin atau interaktif mengalir. Teknik data dalam penelitian ini mengikuti model analisis interaktif(Interactive Model of Analysis) yang akan dijabarkan sebagai berikut:

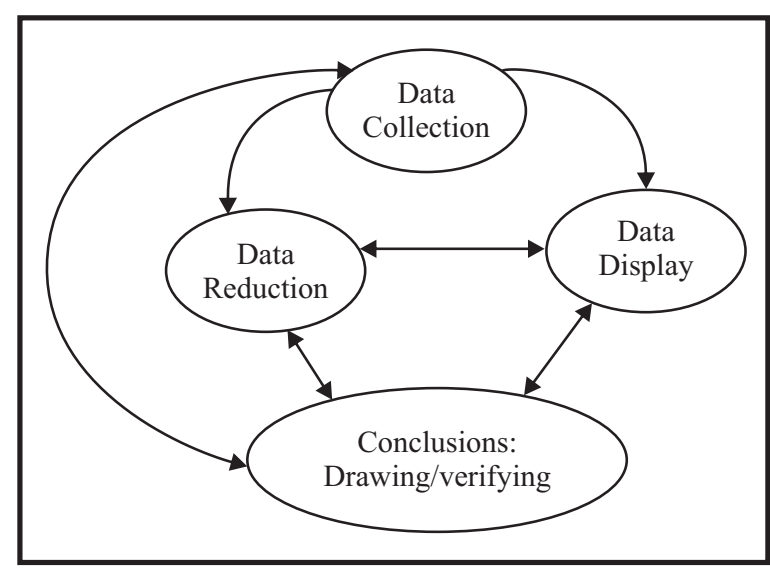

Gambar 1 Interactive Model Analysis Miles, Huberman dan Saldana, 2014: 14
Interaktif model of analysis merupakan teknik analisis yang berbentuk rantai yang mempunyai hubungan yang saling terkait antara satu dengan lainnya. Dari data collection yaitu pengumpulan data penelitian selanjutnya ke data display yaitu penyajian data penelitian. Pada tahap penyajian data ini data juga dapat di reduksi sesuai dengan permasalahan penelitian. Selanjutnya ke tahap conclusion yaitu menyimpulkan dari hasil penelitian.

\section{HASIL DAN PEMBAHASAN}

Mata kuliah perpajakan adalah mata kuliah yang mempunyai banyak perhitunganperhitungan tentang dasar pengenaan pajak. Dasar perhitungan pajak Dengan adanya modul yang dapat digunakan dalam pembelajaran dapat mempermudah mahasiswa dalam mempelajari materi pajak. Modul perpajakan adalah sebuah modul yang berisi materi perpajakan yang dibuat berdasarkan Rencana Pembelajaran Semester (RPS). Dalam modul pajak juga terdapat soal evaluasi setiap babnya. Dengan adanya modul diharapkan mahasiswa dapat mempelajari modul lebih dalam lagi. Selain itu mahasiswa dapat melatih kemampuan diri dalam pemahaman materi dengan cara mengerjakan soal-soal evaluasi yang ada. Dengan demikian mahasiswa dapat mengukur kemampuan pemahaman materi pajaknya setelah mempelajari materinya.

Pembelajaran yang dapat berhasil salah satunya dapat didukung oleh penunjang belajar. Modul adalah salah satu penunjang belajar yang dapat membantu mahasiswa dalam belajar. Mahasiswa dapat mempelajari materi pajak dengan mudah dengan menggunakan modul. Modul yang telah disusun sesuai materi dan terdapat ringkasan pada setiap babnya.

Triangulasi yang digunakan dalam penelitian ini adalah triangulasi data dan triangulasi metode. Triangulasi sumber data 
yaitu membandingkan data yang didapat pada mahasiswa satu dengan mahasiswa lainnya dan data yang didapatkan dari dosen pengampu mata kuliah perpajakan. Data yang didapat dari mahasiswa dan dosen mempunyai jawaban yang sama persepsinya tentang penggunaan modul dalam mata kuliah perpajakan yang mempunyai kelebihan dalam mempermudah mahasiswa dalam belajar pajak. Triangulasi metode yaitu dengan membandingkan hasil observasi dan wawancara yang dilakukan. Observasi yang dilakukan menyimpulkan bahwa pembelajaran yang menggunakan modul mempunyai dampak positif dalam pembelajaran dengan menunjukkan keteraturan dalam mempelajari materi dengan menggunakan modul. Selanjutnya dengan wawancara yaitu mewawancarai mahasiswa yang belajar menggunakan modul lebih mudah dalam pemahaman materinya.

Pada analisis data yang dilakukan tahap pertama yang dilakukan adalah pengumpulan data yaitu data hasil wawancara, hasil observasi, dan berbagai dokumen yang dibutuhkan dalam penelitian. Data yang terkumpul selanjutnya dikembangkan dan dilakukan penajaman data melalui pencarian data selanjutnya. Berdasarkan hasil observasi banyak mahasiswa yang tidak mempunyai banyak referensi mata kuliah perpajakan. Mahasiswa cenderung mencari materi perkuliahan hanya lewat internet saja. Dalam mencari referensi dari internet, banyak sekali informasi materi yang didapatkan mahasiswa tidak kredibel. Mahasiswa hanya asal saja mencari materi yang sesuai tanpa melihat asal-usul dari informasi yang didapatkan. Sehingga materi yang didapatkan mahasiswa adalah materi yang tidak sesuai dengan teori yang ada.

Berdasarkan hasil wawancara yang telah dilakukan, dapat disimpulkan bahwa penggunaan modul mempunyai dampak positif terhadap mahasiswa. Salah satu dampak positifnya adalah meningkatkan pemahaman materi pajak mahasiswa. Mahasiswa yang belajar tidak menggunakan modul cenderung memiliki pemahaman yang sedikit. Hal lain diungkapkan mahasiswa yang belajar dengan menggunakan modul, pembelajaran yang dilakukan lebih teratur dan sistematis sehingga pembelajaran yang menggunakan modul mempermudah mahasiswa dalam memahami konsep pajak.

Tahap selanjutnya adalah reduksi data yaitu analisis yang menajamkan data yang telah didapatkan dan memverifikasi data yang penting dan tidak penting sehingga data yang didapat dapat disimpulkan secara jelas. Data dari hasil wawancara dan observasi yang tidak mendukung untuk penelitian sebaiknya dibuang untuk menghindari terjadinya banyak persepsi yang berbeda.

Tahap selanjutnya adalah penyajian data untuk menemukan data-data yang bermakna dan data yang dapat dijadikan sebagai kesimpulan. Data menunjukkan bahwa pembelajaran menggunakan modul memberikan dampak positif sebesar $85 \%$ terhadap kemampuan pemahaman konsep materi pajak. Mahasiswa dapat menjawab soal-soal evaluasi yang tersedia pada modul.

Pemahaman materi antara satu individu dengan individu yang lain tentu berbeda. Namun pemahaman materi dapat dipersamakan antara satu dengan yang lain. Salah satu cara untuk menyamakan persepsi antar individu adalah memberikan materi atau informasi yang sama dan dengan cara yang sama. Dengan cara ini diharapkan mempunyai persepsi yang sama antar individu.

Tahap terakhir yang dilakukan adalah penarikan kesimpulan. Setelah data yang didapatkan sudah diverifikasi dan di valid. Data dapat disimpulkan berdasarkan hasil dari analisis data yang sebelumnya dilakukan. Kesimpulan dari hasil analisis data adalah 
penggunaan modul perpajakan mempunyai dampak yang positif terhadap konsep pemahaman materi pajak. Pemahaman materi dengan mempelajari modul pajak lebih mudah dipahami jika dibandingkan dengan pembelajaran yang sebelumnya tidak menggunakan modul.

\section{PENUTUP}

\section{Simpulan}

Simpulan dari hasil penelitian ini adalah penggunaan modul mempunyai dampak positif sebesar $85 \%$ terhadap kemampuan pemahaman materi pajak. Dengan adanya modul, pembelajaran mahasiswa tidak lagi terpusat pada gooogle saja tanpa adanya referensi lain yang mendukung. Sebagian besar mahasiswa yang tidak mempunyai referensi materi perpajakan terbantu dengan adanya modul perpajakan. Mahasiswa dapat dengan mudah mempelajari materi perpajakan secara sistematis sesuai dengan Rencana Pembelajaran Semester (RPS). Pemahaman materi pajak dapat ditinjau dari ketrampilan mahasiswa dalam menyelesaikan soal evaluasi dalam modul perpajakan.

\section{Saran}

Modul dapat digunakan dalam semua pembelajaran. Modul yang digunakan sebaiknya disesuaikan dengan materi pembelajaran yang akan dipelajari sehingga dapat mempermudah pembelajaran.

\section{DAFTAR PUSTAKA}

Afifuddin, Beni Ahmad Saebani. (2009). Metodologi Penelitian Kualitatif. Bandung: Pustaka Setia

Daryanto. (2008). Media Pembelajaran. Yogyakarta: Gava Media

Jihad, Asep \& Haris, Abdul. (2008). Evaluasi Pembelajaran. Yogyakarta: Multi Presindo

Lasmiyati, Harta, I. (2014). Pengembangan Modul Pembelajaran untuk Meningkatkan Pemahaman Konsep dan Minat SMP. Pythagoras: Jurnal Pendidikan Matematika. Vol.9 (2): 161-174.

Majid, Abdul. (2014). Strategi Pembelajaran. Bandung: PT Remaja Rosdakarya.

Miles, M.B, Huberman, A.M, dan Saldana, J. (2014). Qualitative Data Analysis, A Methods Sourcebook, Edition 3. USA: Sage Publications. Terjemahan Tjetjep Rohindi Rohidi, UI-Press. Moleong, L. J.2007. Metodologi Penelitian Kualitatif. Bandung: Remaja Rosdakarya.

Prastowo, Andi. (2011). Panduan Kreatif Membuat Bahan Ajar Inovatif. Yogyakarta: Diva Press.

Sugiyono. (2013). Metode Penelitian Pendidikan Pendekatan Kuantitatif, Kualitatif, dan $R \& D$. Bandung: Alfabeta.

Tohirin. (2013). Metode Penelitian Kualtatif dalam Bimbingan dan Konseling. Jakarta: Raja Grafindo Persada. 